\title{
Faktor Risiko Kejadian Mastitis pada Kambing Peranakan Etawah (PE) di Kelompok Ternak Tirto, Kokap, Kulonprogo, Yogyakarta
}

\section{The Risk Factor for Mastitis in Peranakan Etawah (PE) Goat at Tirto Farmer Group, Kokap, Kulonprogo, Yogyakarta}

\author{
Clara Ajeng Artdita', Nurulia Hidayah', Fajar Budi Lestari', Yohanes Wawan Budiyanto², \\ Muhammad Fatan Hidayatullah ${ }^{1}$, Desyah Rahmayanti ${ }^{1}$ \\ 'Program Studi Kesehatan Hewan, Departemen Teknologi Hayati dan Veteriner, Sekolah Vokasi, Universitas \\ Gadjah Mada \\ Jl. Yacaranda Sekip Unit II Depok, Sleman, Yogyakarta \\ clara.ajeng@ugm.ac.id.
}

${ }^{2}$ Puskeswan Kokap UPTD Puskeswan Wilayah Tengah, Dinas Pertanian dan Pangan Kulon Progo

\author{
Diterima $\quad: 24$ Februari 2021 \\ Disetujui : : 12 Maret 2021 \\ Diterbitkan : 31 Agustus 2021
}

\begin{abstract}
Abstrak : Kelompok Ternak Tirto merupakan salah satu peternakan kambing Peranakan Etawah (PE) yang cukup besar dan berada di wilayah Kulonprogo, Yogyakarta. Kambing Peranakan Etawah dikembangbiakkan untuk produksi susu. Intra Mammary Infection (IMI) atau mastitis, khususnya mastitis subklinis, merupakan salah satu penyakit yang menurunkan produksi susu kambing. Tujuan penelitian ini adalah untuk mengetahui faktor risiko yang berkontribusi terhadap terjadinya mastitis subklinis pada kambing PE di Kelompok Ternak Tirto tersebut. Data faktor risiko dikumpulkan menggunakan kuesioner. Metode kuesioner berupa wawancara langsung kepada 19 peternak anggota kelompok ternak ini dan observasi pada saat dilakukan kegiatan pemerahan. Faktor risiko pada kambing PE ditentukan dengan menggunakan odds ratio (OR). Faktor risiko yang berhubungan positif dengan mastitis subklinis pada kambing PE kelompok tani Tirto di Kokap, Kulonprogo, Yogyakarta adalah kebersihan kandang $(O R=1,2)$ dan pembersihan ambing $(O R=8,6)$, sedangkan faktor risiko lainnya adalah asosiasi negatif.
\end{abstract}

Kata Kunci : faktor risiko, kelompok ternak tirto, mastitis, kambing PE

\begin{abstract}
Tirto farmer group is one of the big Peranakan Etawah (PE) goat farm in Kulonprogo, Yogyakarta. Peranakan Etawah goats are excessively breed for the dairy produce called the goat's milk. Intra Mammary Infection (IMI) or mastitis, especially subclinical mastitis, is one of disease which reduce the yield of goat's milk. The aim of this study was to determine the risk factors that contribute to the subclinical mastitis on the PE goats in Tirto farmer group at Kokap, Kulonprogo, Yogyakarta. The data of risk factors were gathered through a questionnaire. The questionnaire was answered by interviewing to 19 farmers, member of Tirto farmer group and milking observation. The risk factors on PE goats were determine with the use of odds ratio (OR). The risk factors which had positive association with the subclinical mastitis on PE goats in Tirto farmer group in Kokap, Kulonprogo, Yogyakarta were house cleaning $(O R=1.2)$ and udder cleaning $(O R=8.6)$, while another risk factor was negative association.
\end{abstract}

Keywords : mastitis, peranakan etawah goat, risk factor, tirto farmer group

\section{Pendahuluan}

Susu segar merupakan cairan yang didapatkan dari kambing yang sehat dan bersih yang diperah dengan teknik yang benar. Dewasa ini, Indonesia telah memanfaatkan susu dari kambing jenis Peranakan Etawah (PE). Kambing ini merupakan persilangan dari kambing jenis Etawah dengan kambing lokal Indonesia (kambing kacang).
Kulonprogo merupakan salah satu kabupaten di Daerah istimewa Yogyakarta (DIY) yang memiliki populasi kambing PE cukup besar. Data dari Dinas Kelautan, Perikanan, dan Peternakan Kulonprogo pada tahun 2012 menyebutkan jumlah populasi kambing PE sebanyak 28,899 ekor yang tersebar di Kecamatan Kokap, Samigaluh, Girimulyo, Pengasih, dan Kalibawang [1]. Susu kambing memiliki berbagai 
keuntungan bagi kesehatan manusia. Susu kambing banyak digemari karena sebagai alternatif bagi konsumen yang memiliki alergi terhadap susu sapi, selain itu kandungan nutrisi yang lebih baik dibandingkan dengan kandungan nutrisi pada susu sapi dan juga mudah dicerna. Hal ini disebabkan karena susu kambing memiliki ukuran butiran lemak yang lebih kecil dibandingkan susu sapi dan memiliki proporsi asam lemak rantai pendek dalam jumlah yang tinggi. Berbagai manfaat inilah yang menyebabkan pangsa pasar susu kambing semakin meningkat $[2,3,4]$.

Kendala kesehatan ternak yang sering dialami ternak perah, termasuk kambing PE, adalah kejadian mastitis atau radang ambing. Kandungan mikroba patogen penyebab mastitis merupakan masalah yang belum tuntas yang terdapat pada susu perah hingga saat ini $[5,6]$. Mastitis merupakan penyakit radang ambing pada ternak perah yang dapat menimbulkan kerugian ekonomi, baik yang menimbulkan gejala klinis maupun yang tidak (subklinis) $[7,8]$. Kejadian, distribusi, dan penyebab mastitis pada peternakan kambing juga telah dilaporkan oleh beberapa negara [9,10,11,12]. Kasus mastitis pada kambing PE dilaporkan menyebabkan kerugian ekonomi bagi peternak kambing PE [13]. Kerugian ekonomi yang diakibatkan mastitis berupa produksi susu yang turun, masa laktasi yang lebih pendek, dan tentu adanya tambahan biaya pengobatan $[7,8]$. Mastitis yang terjadi pada domba dan kambing umumnya adalah mastitis tipe gangrenosa [13]. Kejadian mastitis pada kambing sebagian besar terjadi pada satu minggu sebelum melahirkan ataupun delapan minggu setelah melahirkan [14].

Penentuan kondisi mastitis didasarkan pada somatic cell count (SCC) atau jumlah sel somatik (JSS). Jumlah sel somatik pada umumnya digunakan dalam metode penentuan standar kualitas susu [15]. Terdapat perbedaan kandungan JSS pada kambing dan pada sapi, yaitu kandungan JSS pada kambing lebih tinggi dibandingkan dengan sapi. Hal ini disebabkan karena susu kambing memiliki kandungan apokrin yang lebih tinggi dibandingkan dengan susu sapi yang memiliki kandungan merokrin yang lebih tinggi. Kandungan apokrin yang tinggi pada susu kambing ini menyebabkan jumlah sel somatik dalam susu kambing menjadi lebih tinggi $[16,17]$. Cara diagnosis mastitis subklinis pada kambing adalah dengan menggunakan California Mastitis Test (CMT) dan menunjukkan hasil positif 2 $(++)$ atau positif $3(+++)$. Apabila sudah menunjukkan hasil tersebut, maka diteguhkan dengan pemeriksaan mikrobiologi terhadap bakteri patogen [11,18].

Umumnya, pada peternakan rakyat, para peternak beternak kambing yang dimanfaatkan susunya adalah sebagai usaha sampingan sehingga manajemen pemeliharaannya pun masih sederhana. Oleh karena itu, kondisi ini yang menyebabkan insidensi kasus mastitis. Berbagai upaya pencegahan perlu dilakukan pada kondisi kejadian mastitis subklinis, salah satunya adalah mengenali dan mencermati faktor-faktor resikonya. Faktor resiko tersebut antara lain jumlah anak sekelahiran (litter size), usia induk, jumlah produksi susu dan frekuensi melahirkan. Pengendalian mastitis dapat dilakukan dengan cara terapi antibiotik, namun susu dari ternak yang diberi perlakuan antibiotik biasanya ditolak pasar karena adanya residu antibiotik. Salah satu cara memperbaiki atau mengurangi kejadian mastitis adalah dengan melakukan perbaikan sistem manajemen pemeliharaan [7,19]. Pentingnya mengetahui berbagai faktor resiko kejadian mastitis adalah untuk menemukan kelemahan manajemen peternakan rakyat sehingga faktor resiko ini dapat ditekan yang bertujuan agar diperoleh cara pengembangan sistem peternakan yang sesuai dengan Good Dairy Farming Practices (GDFP) pada peternakan rakyat, khususnya di daerah Kokap, Kulon Progo, Yogyakarta.

\section{Materi dan Metode}

\subsection{Materi Penelitian}

Responden adalah para peternak kambing PE yang tergabung dalam Kelompok Ternak Tirto, Kokap, Kulonprogo. Penelitian ini melibatkan 19 peternak di Kelompok Ternak Tirto, Kokap, Kulonprogo, Daerah Istimewa Yogyakarta.

\subsection{Faktor Risiko}

Faktor risiko dikumpulkan saat wawancara dan pengamatan langsung waktu pemerahan dengan menggunakan kuesioner berupa pertanyaan pilihan. Pertanyaan yang terdapat dalam borang kuesioner antara lain: pembersihan kandang, pembersihan (pemandian) ternak, pembersihan ambing, pencelupan puting (teat dipping), pemisahan kambing sakit, dan pemisahan kambing bunting.

\subsection{Analisis data}

Faktor risiko kejadian mastitis subklinis dianalisis menggunakan odds ratio (OR) [20].

\section{Hasil dan Pembahasan}

Faktor yang mempengaruhi kejadian mastitis subklinis kambing PE adalah pembersihan kandang, pemandian ternak, pembersihan ambing, pencelupan puting, pemisahan kambing sakit, dan pemisahan kambing bunting. Hasil analisa faktor risiko mastitis pada kambing PE di Kelompok Ternak Tirto, Kulonprogo tersaji dalam Tabel 1. 
Tabel 1. Hasil analisa faktor risiko mastitis pada kambing PE di KT Tirto, Kulonprogo dengan analisa Odds Ratio

\begin{tabular}{c|ll}
\hline No & \multicolumn{1}{|c}{ Variabel } & OR \\
\hline $\mathbf{1}$ & Pembersihan kandang & $\mathbf{1 . 2 ^ { * }}$ \\
$\mathbf{2}$ & Pembersihan (pemandian) ternak & $\mathrm{O}$ \\
3 & Pembersihan ambing & $8.6^{*}$ \\
4 & Pencelupan puting (teat dipping) & 0 \\
5 & Pemisahan kambing sakit & 0.2 \\
6 & Pemisahan kambing bunting & 0.13 \\
\hline
\end{tabular}

Ket. : *berasosiasi positif

Berdasarkan Tabel 1, faktor yang sangat mempengaruhi kejadian mastitis adalah pembersihan kandang dan pembersihan ambing. Hal tersebut akan berpengaruh terhadap produksi susu. Kasus mastitis pada kambing PE dilaporkan menyebabkan kerugian ekonomi bagi peternak kambing PE [13]. Kerugian ekonomi oleh mastitis berupa turunnya produksi susu, masa laktasi kambing menjadi lebih pendek, dan bertambahnya biaya pengobatan $[7,8]$. Kejadian mastitis erat hubungannya dengan manajemen pemeliharaan maupun pemerahan. Kambing PE yang telah berumur tua, dan umur sapih dilakukan kurang dari satu bulan merupakan salah satu contoh manajemen pemeliharaan yang dapat menyebabkan mastitis subklinis. Perbaikan manajemen pemerahan dapat menekan kejadian mastitis [19].

\subsection{Pembersihan kandang dan ambing}

Faktor risiko yang berpengaruh terhadap kejadian mastitis di Kelompok Ternak Tirto, Kulonprogo adalah pembersihan kandang dan pembersihan ambing. Pembersihan kandang memiliki asosiasi positif terhadap kejadian mastitis $(\mathrm{OR}=1.2)$. Salah satu faktor kejadian mastitis pada kambing PE disebabkan oleh faktor ketidakteraturan pembersihan kandang, yang berarti bahwa kandang kambing PE yang tidak teratur dibersihkan dapat mempengaruhi terjadinya mastitis $\mathbf{1 . 2}$ kali apabila dibandingkan dengan kandang dan lingkungan sekitar kandang yang dibersihkan secara teratur atau rutin. Faktor sanitasi lingkungan menjadi penting untuk mencegah kejadian penyakit pada ternak.

Kandang atau lingkungan tempat hidup ternak juga perlu dibersihkan secara rutin bertujuan untuk menciptakan lingkungan yang bersih dan sehat sehingga kesehatan ternak dapat terjaga. Lingkungan kandang yang tidak dibersihkan secara rutin, tentunya akan dapat menyebabkan turunnya daya tahan tubuh kambing serta dapat memunculkan bibit penyakit. Kandang yang lembab dan tidak bersih disertai dengan daya tahan tubuh yang lemah memungkinkan agen penyakit (patogen) menginfeksi tubuh ternak bahkan bisa menginfeksi ambing melalui lubang saluran pada puting (teat canal) [21].

Kejadian mastitis pada kambing PE bisa terjadi karena faktor ketidakteraturan pembersihan ambing, Adanya asosiasi positif antara pembersihan ambing dan mastitis (OR=8.6), artinya ambing kambing $\mathrm{PE}$ yang tidak teratur dibersihkan bisa mempengaruhi terjadinya mastitis 8.6 kali daripada yang dibersihkan sebelum pemerahan. Pembersihan ambing secara rutin berperan untuk mencegah kejadian mastitis $[\mathbf{2 1 , 2 2}]$, selain itu pembersihan ambing apabila hanya dilakukan dengan menggunakan air keran juga rawan kejadian mastitis. Air keran dapat terkontaminasi bakteri Pseudomonas aeroginosa dan apabila digunakan untuk membasuh ambing maka dapat menyebabkan mastitis klinis pada domba [23].

\subsection{Pembersihan ternak, pencelupan putting dan pemisahan kambing}

Peternak melakukan pembersihan kambing PE sebelum pelaksanaan proses pemerahan terutama pada bagian ambing. Hal tersebut dilakukan untuk uapaya menjaga kebersihan ternak. Proses pencelupan putting (teat dipping) dilakukan setelah pemerahan untuk mengurangi resiko mastitis. Faktor risiko mastitis yang berasosiasi negatif terhadap kejadian penyakit mastitis di Kelompok Ternak Tirto, Kokap, Kulonprogo adalah pemandian atau pembersihan ternak $(\mathrm{OR}=\mathrm{O})$, pencelupan putting (teat dipping) $(\mathrm{OR}=\mathrm{O})$, pemisahan kambing sakit $(\mathrm{OR}=\mathbf{0 . 2})$, dan pemisahan kambing bunting $(\mathrm{OR}=0.13)$.

Faktor memandikan ternak tidak berpengaruh terhadap kejadian penyakit mastitis di Kelompok Ternak Tirto, Kokap, Kulonprogo. Ternak yang rutin dimandikan dapat berpengaruh terhadap kebersihan badan ternak sekaligus mengurangi kuman yang terdapat di badan [22]. Teat dipping penting dalam manajemen pemerahan karena dapat mencegah masuknya kuman penyebab mastitis melalui saluran puting menuju ke ambing, terlebih apabila frekuensi pemerahan dilakukan lebih dari 1 kali pemerahan maka dapat menyebabkan otot sphincter mengendor [24]. Teat dipping dengan desinfektan sangat efektif untuk mengurangi kejadian mastitis [25]. Pada Kelompok Ternak Tirto ini teat dipping tidak berpengaruh pada kejadian mastitis, hal ini dapat dikarenakan berdasarkan hasil wawancara bahwa pemerahan hanya dilakukan 1 kali dalam sehari. Pemisahan kambing sakit berperan 0.2 kali dan pemisahan kambing bunting berperan 0.13 kali sebagai faktor resiko penyebab mastitis, oleh karena itu pemisahan kambing sakit dan pemisahan kambing bunting tidak berpengaruh pada kejadian mastitis di Kelompok Ternak Tirto, Kokap, Kulonprogo; Namun, pemisahan kambing sakit dan kambing bunting tetap perlu disarankan.

\section{Kesimpulan}

Analisa statistik Odds Ratio dapat digunakan untuk menentukan faktor-faktor risiko yang berperan dalam kejadian mastitis di Kelompok Ternak Tirto, 
Kulonprogo, Yogyakarta. Faktor risiko yang berpengaruh di Kelompok Ternak Tirto, Kulonprogo, Yogyakarta adalah pembersihan kandang dan pembersihan ambing.

\section{Ucapan Terima Kasih}

Terima kasih disampaikan kepada peternak kambing PE di Kelompok Ternak Tirto, Kulonprogo, Yogyakarta dan drh. Yohanes Wawan Budiyanto atas kerjasama yang baik selama penelitian berlangsung.

\section{Referensi}

[1] Sutarmi, "Kulonprogo berhasil kembangkan Kambing Ettawa", Antara jogja.com., 2013. [ONLINE]

https://jogja.antaranews.com/berita/313959/kulo n-progo-berhasil-kembangkan-kambing-etawa

[Accessed: 15 Agustus 2020].

[2] R.D. Moeljanto and B.T.W. Wiryanta, "Efficacy and Benefits of Goat Milk: The Best Milk of Ruminan". Jakarta: Agro Media Pustaka, 2002.

[3] L.S. Ceballos, E.R. Morales, G.D.L.T. Adarve, J.D. Castro, L.P. Martinez, dan M.R.S. Sampelayo, "Composition of goat and cow milk produced under similar conditions and analyzed by identical methodology", J Food Comp Analysis, vol. 22, no. 4, pp. 322-329, 2009.

[4] F. Yangilar, "As a potentially functional food: goat's milk and products", Journal of food and nutrition research, vol. 1, no. 4, pp. 68-81, 2013.

[5] O.M. Radostits, D.C. Blood, C.C. Gay, and K.W. Hinchkliff, "Veterinary Medicine". 9th ed. London: ELBS-Bailliere Tindal, 2000.

[6] D. Winarso, "Hubungan Kualitas Susu dengan Keragaman Genetik dan Prevalensi Mastitis Subklinis di Daerah Jalur Susu Malang Sampai Pasuruan”. Jurnal Sains Veteriner, vol. 26, no. 2, pp. 246-323, 2008.

[7] P. Moroni, Pisoni, G.Ruffo and P.J. Boetter, "Risk factors for intramammary infections and relationship with somatic cell counts in Italian dairy goats". Prev Vet Med, vol. 69, no. 3-4, pp. 163-173, 2005.

[8] T. Mørk, B. Kvitle, T. Mathisen, and H.J. Jørgensen, "Bacteriological and molecular investigations of Staphylococcus aureus in dairy goats". Veterinary microbiology, vol.141, no. 1, pp. 134-141, 2010.

[9] J.A. Ameh and I.S. Tari, "Observations on the prevalence of caprine mastitis in relation to predisposing factors in Maiduguri”. Small Rumin. Res, vol. 35, pp.1-5, 2000.
[10] E.N. Ndegwa, C.M.Mulei, and S.J. Munya, "Risk factors associated with subclinical mastitis in Kenyan dairy goats". Israel Journal of Veterinary Medicine, vol. 56, pp. 1-6, 2000.

[11] S. McDougall, W.Pankey, C. Delaney, J. Barlow, P.A. Murdough, and D. Scruton, "Prevalence and incidence of subclinical mastitis in goats and dairy ewes in Vermont USA", Small Rumin. Res., vol. 46, no. 2-3, pp:115-121, 2002.

[12] A. Wakwoya, B. Molla, K. Belihu, J. Kleer, and G. Hildebrandt, "A Cross-sectional Study on Prevalence, Antimicrobial Susceptibility Pattern and Associated Bacterial Pathogens of Goat Mastitis", Intern. J. Appl. Res. Vet. Med., vol.4, pp. 169-176, 2006.

[13] A. Purnomo, Hartatik, Khusnan, S.I.O. Salasia, and Sugiyono. "Isolasi dan Karakterisasi Staphylococcus aureus asal Susu Kambing Peranakan Ettawa", Media Kedokteran Hewan, vol.22, no.3, pp. 142-147, 2006.

[14] M. Tormod, S. Waage, T. Tollersrud, B. Kvitle, and S. Sviland, "Clinical mastitis in ewes; bacteriology, epidemiology and clinical features". Acta Vet Scand., vol. 49, no. 23, pp.1-8, 2007.

[15] M.J. Green, L.E. Green, Y.H. Schukken, A.J. Bradley, E.J. Peeler, H.W. Barkema, Y. de Haas, V.J. Collis, and G.F. Medley, "Somatic cell count distributions during lactation predict clinical mastitis", Journal of Dairy Science, vol. 87, pp: 1256-1264, 2004.

[16] M.J. Paape and A.V. Capuco, "Cellular defense mechanism in the udder and lactation of goat". J. Anim. Sci., vol. 75 no. 2, pp. 556-565, 1997.

[17] P. Schneiderová, "Goat milk and productions of lactoferrin". Animal Science Paper and Reports, vol. 22, pp. 17-25, 2004.

[18] Y. Persson and I. Olofsson, "Direct and indirect measurement of somatic cell count as indicator of intramammary infection in dairy goats". Acta Vet. Scand., vol. 53, no. 15, pp. 1-5, 2011.

[19] G. Koop, T. Werven, H.J. Schuiling, and M. Nielsen. "The effect of subclinical mastitis on milk yield in dairy goat", J. Dairy Sci, vol. 93, no. 12, pp:5809-5817, 2010.

[20] M. Thrusfield, "Veterinary epidemiology. 2th ed". Department of Veterinary Clinical Studies Royal (Dick) School of Veterinary Study University of Edinburgh. Edinburg: Blackwell Science., pp. 224-227, 1995. 
[21] Subronto, "Ilmu Penyakit Ternak II (Mamalia)". Yogyakarta: Gadjah Mada University Press, pp: 320-33, 2007.

[22] Subronto, "Ilmu Penyakit Ternak (Mamalia)", Yogyakarta: Gadjah Mada University Press, pp: 14-18; 44-47, 2003.

[23] L. Heras, A. Dominguez, I. Lopez, and J.F. Garayzabal, "Outbreak of acute ovine mastitis associated with Pseudomonas aeruginosa infection", Vet Rec., vol. 145, no. 5, pp: 111-112, 1999.

[24] G. Marogna, C. Pilo, A. Vidili, S. Tola, G. Schianchi, and SG. Leori, "Comparison of clinical findings, microbiological result, and farming parameters in goat herds affected by recurrent infectious mastitis". Small Rumin Res, vol. 102, pp. 74-83, 2012.

[25] A. Contreras, D. Sierra, A. Sanchez, J.C. Corrales, J.C. Marco, M.J. Paape, and C. Gonzalo, "Mastitis in small ruminants”. Small Rumin. Res., vol. 68, no. 1-2, pp: 145-153, 2007. 